\title{
Aikuiskasvatuskuulumisia Euroopasta
}

\author{
Aikuiskasvatuksen Tutkimusseuran sihteeri, \\ tutkijatohtori Kristiina Brunila on reilun vuoden \\ ajan tarkkaillut aikuiskasvatuskenttää Euroopan \\ mittakaavassa. Paikka ESREA:n (Europan Society \\ for Research on Eduation of Adults) johtokunnassa \\ on muun muassa osoittanut, että Suomi on \\ aikuiskasvatuksen mallioppilas.
}

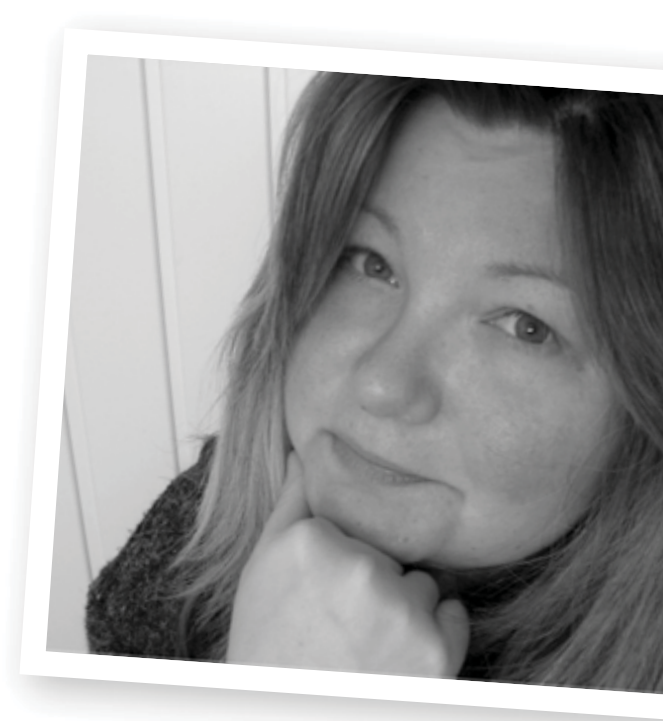

Aloitin ESREA:n (Europan Society for Research on Eduation of Adults) johtokunnassa työskentelyn vuoden 2011 alussa, kun johtokunnassa aktiivisesti toiminut Anja Heikkinen luopui tehtävästään. Nyt kauteni puolivälissä on hyvä hetki kertoa ESREA:sta ja toimimisestani siellä.

ESREA:n tehtävänä on edistää ja tukea aikuiskasvatuksen (adult education and learning) tutkimusta Euroopan laajuisesti. Toimittuani johtokunnassa reilun vuoden ajan olen saanut huomattavasti paremman mielikuvan siitä, kuinka laaja-alaista ja moninaista aikuiskasvatukseen liittyvä toiminta $\mathrm{Eu}$ roopassa on. Aikuiskasvatus ei sen perusteella ole häviämässä mihinkään. Mielenkiintoista onkin ollut havaita, että ESREA:n jäsenmäärä on kasvanut, ja erityisesti nuoria tutkijoita on tullut enemmän mukaan.
Olemme kokoontuneet kaksi kertaa vuodessa. Viime vuonna kokoonnuimme Genevessä ja Berliinissä, nyt keväällä Sevillassa ja syksyllä Roskildessa. Eurooppalaiseen tapaan aloitamme vilkkaalla kuulumisten vaihdolla. Kokoukset ovat tiiviitä kahden työpäivän pituisia rupeamia, joiden aikana käydään läpi mittava määrä asioita.

\section{PÄÄTÖKSENTEKO VIE AIKAA}

Johtokunta on varsin keskusteleva, joskin siellä vältetään ottamasta voimakkaita kantoja puoleen tai toiseen, mikä itselleni on ollut jossain määrin vaikeaa omaksua. Tutkijana olen kasvanut siihen, että kaikki tutkimus on väistämättä poliittista, oli se sitten tutkimuksessa eksplikoituna tai ei. Mikään ei näin ollen ole viatonta. Tällöin ei myöskään ole olemassa niin 
kutsuttuja objektiivisia tai neutraaleja tutkimusnäkökulmia, jolloin tutkimuksen poliittisuus tunnistetaan ja siitä keskustellaan yhteisesti.

ESREA:ssa sen sijaan pyritään ainakin ideaalitasolla kaiken aikuiskasvatukseen liittyvän tutkimuksen tasa-arvoisuuteen. Itse tasa-arvoa pitkään tutkineena olen tietoinen siitä, että näennäinen yksimielisyys ja moniäänisyys eivät tarkoita mitenkään itsestään selvästi tasavertaisuutta, moniäänisyyttä ja oikeudenmukaisuutta.

Suomalaiseen kokouskulttuuriin verrattuna asioista päätetään ESREA:ssa huomattavasti hitaammin. Päätöksiä pyöritellään pitkään, jotta varmasti kaikkien näkökulmat tulevat esille. Johtokunnan jäsenet koostuvat tutkijoista Tanskasta, Ruotsista, Suomesta, Iso-Britanniasta, Saksasta, Ranskasta, Puolasta, Portugalista, Kreikasta, Virosta ja Italiasta. Johtokunnan presidenttinä on toiminut jo usean kauden ajan Henning Salling Olesen Tanskasta. Sihteerinä on toiminut Andreas Fejes Ruotsista, mutta hän jättää nyt tehtävänsä tultuaan valituksi Linköpingin yliopistoon aikuiskasvatuksen professoriksi. Hänen sijalleen valittiin edellisessä kokouksessa Sofia Nyström.

\section{KOKOUKSISSA KÄYTETÄÄN USEITA KIELIÄ}

ESREA:n toimintaan kiinni pääseminen vei minulta ensimmäisen vuoden. Vasta toisen vuoden alkaessa aloin pikkuhiljaa hahmottaa, mistä kaikesta toiminnassa on kyse ja miten erilaisin tavoin voin itse johtokunnassa toimia niin, että en tule myöskään loukanneeksi edellä mainittua "antaa kaikkien kukkien kukkia” -periaatetta. Tärkeitä ovat sielläkin henkilökohtaiset suhteet. Kun pääsee tutustumaan kunnolla muihin ja tätä kautta verkostoitumaan, on ihan eri asia alkaa suunnitella esimerkiksi yhteisiä eurooppalaisia kesäkouluja, julkaisuja, konferensseja ja muuta toimintaa.

Olen pitänyt johtokunnan toiminnasta paitsi siksi että kaikki suhtautuvat siellä intohimoisesti ai- kuiskasvatuksen tukemiseen myös sen kielipolitiikan takia. Johtokunnan kieli on englanti, mutta kokousten aikana puhutaan lisäksi ranskaa, saksaa, ruotsia, portugalia, tanskaa ja jopa suomea, koska kollegani Larissa Jögi Tallinnan yliopistosta osaa kieltä hyvin. Kenenkään ei oleteta puhuvan täydellistä englantia, mikä uskoakseni vähentää kynnystä osallistua kokouksiin. Kielipolitiikka on viety myös RELA-lehteen (The European Journal for Research on the Education and Learning of Adults), johon voi lähettää artikkelikäsikirjoituksia muillakin kielillä kuin englanniksi.

\section{KIRJOITTAJIA JA KONFERENSSIVÄKEÄ KAIVATAAN SUOMESTA}

ESREA:n keskeisin toimintamuoto ovat tutkimusverkostotapaamiset. Tutkimusverkostoja on tällä hetkellä 11 , ja tapaamisia järjestään säännöllisesti. $\mathrm{Ne}$ ovat keskustelevia ja niihin kannattaa mennä mukaan, kun sopiva löytyy. Itse koetan päästä ainakin kahteen tutkimusverkostoon, mutta rahoituksen saaminen verkostoon osallistumiseen voi joskus asettua ongelmaksi. Erityisesti nuoria tutkijoita kannustetaan osallistumaan näihin tapaamisiin. Muutamalla hakijalle pystytään myöntämään pieni taloudellinen tuki osallistumiseen. Tutkimusverkostot ovat julkaisseet omista konferensseistaan myös kirjoja, joita suosittelen niiden monipuolisuuden takia.

ESREA:n julkaisema RELA-lehti on referee-käytäntöä noudattava open access -lehti. Siihen otetaan vastaan artikkelikäsikirjoituksia aikuiskasvatustieteen ja aikuiskoulutuksen alueelta. Lehden advisory board on kansainvälinen, ja Suomen edustajana on siellä aktiivisesti toiminut Karin Filander Tampereen yliopistosta. Kannustan kaikkia lämpimästi tutustumaan lehteen ja lähettämään sinne artikkeleita.

Muutakin julkaisutoimintaa ESREA:lla on. Järjestön johtokunta on hiljattain tehnyt julkaisusopimuksen Sense Publishers -kustantamon kanssa kir- 
jasarjasta liittyen aikuiskasvatuksen tutkimukseen Euroopassa. Johtokunta valitsi kokouksessa toimituskunnan, johon valittiin minun ohella Henning Salling Olesen Tanskasta, Emilio Lucio-Villegas Espanjasta ja Barbara Merrill Iso-Britanniasta. Kirjojen teemat kytketään ESREA:n tutkimusverkostoihin. Olisi hienoa saada kirjoittajia myös Suomesta mukaan.

ESREA:n kolmen vuoden sykleissä toteutettava konferenssi (triennial conference) lienee sen toiminnan kohokohtia. Seuraavan kerran konferenssi järjestetään syyskuussa 2013 Berliinissä. Toivottavasti seuraavassakin konferenssissa nähdään paljon suomalaisia. Lisätietoja konferenssista löytyy järjestön verkkosivuilta.

Olen myös suunnitellut yhdessä johtokunnan jäsenen Georgios Zarifiksen kanssa kansainvälistä tilaisuutta, jossa EU-tason poliittiset päättäjät ja aikuiskasvatuksen tutkijat kokoontuvat keskustelemaan keskenään. Tilaisuudesta on tarkoitus tehdä säännöllinen keskustelufoorumi, joka parhaimmillaan voisi lähentää päätöksentekijöitä ja tutkijoita. Georgioksen kanssa selvitämme parhaillaan, millä tavalla tilaisuus voidaan järjestää. Näyttää siltä, että ainakin ensimmäinen tilaisuus kytketään ESREA:n konferenssin yhteyteen.

\section{JUHLAPUHEISTA KONKRETIAAN}

On kiinnostavaa huomata, kuinka Suomi nähdään keskusteluissamme usein niin sanottuna mallioppilaana. Luemme tilastojen mukaan RELA-lehteä aktiivisesti, toimimme tutkimusverkostoissa vilkkaasti ja aikuiskasvatukseen liittyvä toimintamme näyttää järjestäytyneeltä ja tehokkaalta. Toki muistin johtokunnalle mainita viime keväänä Helsingin yliopistossa järjestetyn Aikuiskasvatuksen tutkijatapaamisen, joka rikkoi noin 200 osallistujallaan kaikkein aikojen ennätykset. Sanottakoon, että mainitessani kyseisen osallistujamäärän, monien kulmakarvat kohosivat.
ESREA:ssa toimimisen myötä en ole voinut olla kiinnittämättä huomiota myöskään siihen, että aikuiskasvatukseen liittyvä toiminta näyttäytyy vielä ainakin jossain määrin valkoisten korkeasti koulutettujen Länsi-Eurooppalaisten englantia sujuvasti puhuvien heteroseksuaalisten miesten foorumina - jos tilannetta tarkastellaan esimerkiksi sen osalta, ketkä toimijat näyttäytyvät kentällä aktiivisina, keiden nimet nousevat keskusteluissa esiin, keiden toiminta ylipäätään noteerataan ja keitä ajatellaan lupaavina tulevaisuuden vaikuttajina aikuiskasvatuksessa. Vaikka aikuiskasvatuksen tavoitteena voi yleisesti ottaen pitää moniäänisyyttä, demokraattisuutta ja oikeudenmukaisuutta, on siinä vielä tekemistä, että juhlapuheista siirrytään ihan sinne konkretiaan asti.

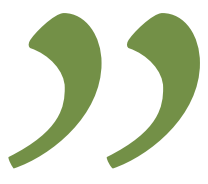

\section{LISÄTIETOA}

ESREA:n sivuilta löytyy tietoa muun muassa tutkimusverkostoista: www.esrea.org

RELA-lehti ilmestyy kahdesti vuodessa: www.rela.ep.liu.se 